일반논문-09-14-2-11

$$
\text { 실감 방송에서의 } 3 \mathrm{D} \text { 깊이/모양 지각감 왜곡의 측정 }
$$

이 형 철 $)^{\ddagger}$

\title{
Measurement of the Perceptual Distortion of 3D Depth/Shape in Realistic Broadcasting
}

\author{
Hyung-Chul O. $\mathrm{Li}^{\mathrm{a})^{\ddagger}}$
}

요 약

자연 3D 환경에서와 달리 3D 디스플레이를 통해 제시되는 대상의 깊이와 모양은 관찰거리에 따라서 체계적으로 왜곡되어 지 각된다. 동일한 $3 \mathrm{D}$ 디스플레이를 시청하는 다수의 시청자가 상이한 $3 \mathrm{D}$ 깊이감과 모양감을 지각하는 것은 바람직하지 않은데, 이 와 같은 $3 \mathrm{D}$ 깊이감/모양감 왜곡 문제를 해결하기 위해서는 3D 깊이감과 모양감의 왜곡정도를 측정하는 정교한 도구가 필요하다. 본 연구는 $3 \mathrm{D}$ 깊이감과 모양감 왜곡의 문제를 해결하기 위한 기반연구로서 $3 \mathrm{D}$ 깊이감과 모양감 왜곡정도를 측정할 수 있는 깊이 감/모양감 왜곡 측정도구를 제안한다.

\section{Abstract}

The 3D shape as well as the depth of an object presented on a 3D display is perceptually distorted depending on viewing distance. It is quite undesirable that different observers perceive different depth and shape from an object displayed on a 3D monitor. To resolve the problem of perceptual distortion of 3D depth and shape, the degree of the distortion should be measured appropriately. As a basis for resolving these problems, the present research suggests an instrument for measuring the degree of the perceptual distortion of 3D depth and shape.

Key Words : 3D depth, shape, perceptual distortion, measurement

\section{I. 서 론}

$3 \mathrm{D}$ 디스플레이는 인간이 자연 $3 \mathrm{D}$ 환경에서 획득하게 되는 양안시차(binocular parallax)를 2차원 화면을 통해 시청자에 게 전달하는 시스템이다. $3 \mathrm{D}$ 실감방송의 핵심은 자연 $3 \mathrm{D}$ 환

a) 광운대학교 산업심리학과

Department of Industrial Psychology, Kwangwoon University

\# 교신저자 : 이형철 (hyung@kw.ac.kr)

※본 연구는 지식경제부 및 정보통신연구진흥원의 IT신성장동력핵심기 술개발사업(2007-F-037-02) 지원을 받아 수행하였음.

· 접수일(2008년12월2일), 수정일(2009년1월18일), 게재확정일(2009년 2월 23일)
경에서 인간이 직접 접하는 $3 \mathrm{D}$ 대상과 동일대상을 $3 \mathrm{D}$ 디스 플레이를 통하여 간접적으로 접하는 $3 \mathrm{D}$ 대상이 지각적으로 구별하기 힘들 정도로 유사해야 한다는 데 있다. 아쉽게도 현 재의 $3 \mathrm{D}$ 방송기술은 자연환경에서 인간이 접하는 $3 \mathrm{D}$ 대상과 $3 \mathrm{D}$ 디스플레이를 통하여 간접적으로 접하는 3D 대상에 대한 지각에서 뚜렷한 차이를 유발한다. 가장 큰 차이는, 실제 자연 $3 \mathrm{D}$ 환경에서 접하는 $3 \mathrm{D}$ 대상은 관찰거리, 관찰시점, 관찰환 경에 관계없이 동일한 $3 \mathrm{D}$ 깊이와 $3 \mathrm{D}$ 모양을 갖는 것으로 지 각되는데 반하여 $3 \mathrm{D}$ 디스플레이를 통하여 지각되는 $3 \mathrm{D}$ 대상 은 관찰거리, 관찰시점 및 관찰환경에 따라서 $3 \mathrm{D}$ 깊이감과 
$3 \mathrm{D}$ 모양감이 체계적으로 왜곡되어 지각된다는 점이다. 자연 $3 \mathrm{D}$ 환경에서 접하는 대상으로부터 획득되는 지각감과 동일 한 지각감을 유발하는 3D 실감방송을 구현하기 위해서는 현 재의 $3 \mathrm{D}$ 디스플레이가 유발하는 3D 깊이감과 모양감의 왜곡 이 객관적이고도 안정성있게 수량화되어 측정되어야 한다.

Woods, Docherty 그리고 Koch(1993)는 입체 카메라 시 스템과 디스플레이 시스템에서 화면시차 또는 궁극적으로 입체 영상에 영향을 미치는 관련 파라미터와 투사법을 기 술하고 각 파라미터에 따라서 대상간의 깊이(object distance)에 비해 이에 대응하는 영상에서의 거리(image distance)가 어떻게 체계적으로 왜곡되는지, 그리고 실제 대상 에서의 평행한 면이 어떻게 이미지 상에서 곡률형태로 왜 곡되는지를 보여 주었다 ${ }^{[1]}$. 비슷한 맥락에서 기하학적 3차 원 영상의 왜곡과 관련된 3차원 영상촬영, 표시 및 관찰자 와의 상관관계 분석에 대한 시도가 있었다 ${ }^{[2]}$.

본 연구의 목적은 입체카메라 시스템과 디스플레이 시스 템에서의 관련된 파라미터가 변함에 따라서 어떻게 이미지 가 왜곡되는지를 측정하는데 있지 않고, 최종적으로 시청자 에게 제시되는 동일한 입체영상이 관찰조건에 따라서 어떻 게 지각적으로 왜곡되는지를 측정하는 데에 있다. 여러 관련 파라미터가 변화함에 따라서 동일 대상에 대한 입체영상이 어떻게 왜곡되는지를 분석하는 것은 충분히 의미가 있는 작 업이다. 하지만, 궁극적으로 입체영상은 입체영상 자체로서 보다는 시청자에게 제시되어 $3 \mathrm{D}$ 입체감을 형성할 때에 의미 가 있다. 3차원 공간을 2차원 망막에 투사하면 당연히 관찰 거리와 양안간 거리에 따라서 기하학적 법칙에 따라 망막
이미지가 변화한다. 흥미롭게도 인간의 시각시스템은 자연 의 $3 \mathrm{D}$ 환경에서 관찰거리 및 방향등의 조건이 변함에 따라 망막 이미지가 변화함에도 불구하고 일반적으로 3차원 공간 의 고유속성을 항상성있게 지각하는데, 이를 $3 \mathrm{D}$ 깊이 항상 성(perceptual depth constancy)이라고 한다 ${ }^{[3,4]}$. 이와 같은 맥락에서 3차원 영상의 왜곡에 영향을 미치는 파라미터가 궁극적으로 3차원 지각왜곡을 유발하는지를 규명하는 것이 추가적으로 필요하며 본 연구에서 제안하는 깊이/모양 지각 왜곡 측정 기법이 이와 같은 규명에 이용될 수 있을 것이다.

\section{II. 본 론}

\section{1. 인간 3D 지각 시스템의 특성과 3D 디스플레이에서의 깊이모양지각 왜곡}

$3 \mathrm{D}$ 디스플레이에 제시되는 영상이 시청환경 조건에 따 라서 지각적으로 왜곡되고 이 왜곡의 측정이 중요한 문제 임을 이해하기 위해 기본적으로 인간의 $3 \mathrm{D}$ 지각시스템에 대한 이해가 필요하다. 일반적으로 관찰거리 변화에 따라 서 양안시차 양이 감소함에도 불구하고 일반적인 자연 $3 \mathrm{D}$ 환경에서는 인간 관찰자가 대상의 깊이와 모양을 안정적으 로 지각한다는 것을 이해할 필요가 있다. 특히, 자연 $3 \mathrm{D}$ 환 경과 달리 인공적인 $3 \mathrm{D}$ 디스플레이 환경에서 깊이와 모양 지각 왜곡이 발생함을 이해할 필요가 있다.

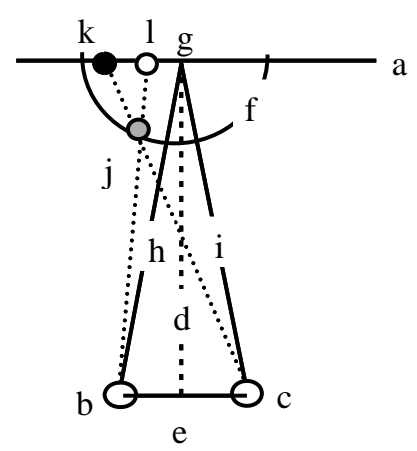

a: 스크린 또는 모니터

$\mathrm{b}, \mathrm{c}$ : 좌안/우안 (또는 좌측/우측 카메라)

$\mathrm{d}$ : 관찰거리

$\mathrm{e}$ : 양안간 거리

f: 수리적 대상 (여기서는 반 원통체)

$\mathrm{g}:$ 수렴점 (또는 응시점)

$\mathrm{h}, \mathrm{i}$; 좌안/우안의 수렴점을 응시할 때의 응시선

$\mathrm{j}:$ 수리적 대상 표면위의 임의의 점

$\mathrm{k}, \mathrm{l}$ : 수리적 대상위의 임의의 점을 투사하였을 때 화면에 투사되는 우안/좌안

영상, 이들의 차이가 화면시차

그림 1. 반원통체 모형 입체영상 구성을 위한 도식과 관련 파라미터들

Fig 1. Parameters relevant to the construction of the model of half-cylindrical stereo-images 


\section{1 양안시차에 영향을 미치는 파라미터}

양안시차는 관찰거리의 제곱에 반비례한다. 그림 1 은 고 정된 깊이와 모양을 갖는 반원통체를 특정한 관찰거리에서 관찰할 때 양쪽 눈의 망막에 형성될 양안시차에 대응하는 화면시차에 영향을 미치는 파라미터를 도식적으로 나타낸 것이다. 양안시차 또는 화면시차에 영향을 미치는 파라미 터는 대상의 물리적 깊이, 관찰거리와 양안간 거리인데, 대 상의 깊이와 양안간 거리는 변화하지 않고, 결국, 주어진 대상에 대한 양안시차에 영향을 미치는 변인은 주로 관찰 거리인데, 이 때 관찰거리가 증가함에 따라서 주어진 대상 의 양안시차 또는 화면시차는 관찰거리 제곱에 반비례하여 감소한다. 즉, 관찰거리가 증가할수록 궁극적으로 양안시 차는 0 에 근접하게 된다 ${ }^{[5][6][7]}$.

\section{$1.23 \mathrm{D}$ 깊이항상성}

일상생활에서의 경험에 비추어 보면, 특정대상에 대한 3 차원 깊이감은 관찰거리와 관계없이 일정하게 유지되는데, 이를 3D 깊이 항상성(perceptual depth constancy)이라고 한다 ${ }^{[8,9]}$. 동일대상의 깊이에 대응하는 양안시차가 관찰거 리의 제곱에 반비례하여 감소함에도 불구하고 자연환경에 서 인간의 $3 \mathrm{D}$ 시각 시스템이 $3 \mathrm{D}$ 깊이 항상성을 갖는다고 하는 것은 우리의 시각시스템이 어떤 형태로든 관찰거리에 따라서 체계적으로 변화하는 양안시차의 문제를 극복한다 는 것을 시사한다.

인간의 $3 \mathrm{D}$ 깊이 항상성에 관한 두 가지 대표적인 이론이 있는데, 하나는 척도화 이론(scaling theory)이고 다른 하나 는 규제이론(constraint theory)이다. 척도화 이론에 의하면 우리의 시각기제는 양안시차 정보에만 근거하여 깊이를 지 각하지 않는데, 왜냐하면 양안시차는 대상까지의 관찰거리 에 따라서 체계적으로 변화하기 때문이다. 이 이론에 의하 면 우리의 시각기제는 대상까지의 관찰거리에 대한 정보로 양안시차를 척도화하여 실제 대상의 깊이를 계산한다 ${ }^{[6]}$. 반 면, 규제이론에 의하면 우리의 시각기제는 관찰거리가 변 화하더라도 대상의 깊이에 대한 일관된 정보를 항상성있게 외부세계에서 찾아내고 이에 기반하여 $3 \mathrm{D}$ 깊이를 지각한 다고 주장한다 ${ }^{[7]}$. 앞서 기술한 이론들은 각 각 자신의 이론 이 타당함을 지지하는 경험적 데이터를 제시하였는데, 정
도의 차이는 있지만 두 이론 모두 관찰거리가 변화함에도 불구하고 인간의 $3 \mathrm{D}$ 시각 시스템이 어떻게 자연 $3 \mathrm{D}$ 환경 에서 안정적으로 $3 \mathrm{D}$ 깊이감을 지각할 수 있는지를 제시하 고 있다.

\section{$1.33 \mathrm{D}$ 모양 항상성}

$3 \mathrm{D}$ 깊이 항상성이 깊이차원에서의 항상성 개념인데 비 하여, $3 \mathrm{D}$ 모양 항상성에는 최소한 두 개의 차원이 관여하는 데, 깊이 차원과 크기 차원이 동시에 고려되는 경우로서 표 면 곡률(curvature)이 이에 해당한다. 그림 2는 깊이차원이 단독으로 고려된 경우와 깊이와 크기 차원이 동시에 고려 된 경우의 표면 곡률 개념의 차이를 보여준다. 그림 2의 가) 는 크기(반지름)와 깊이가 동일한 반원이다. 이 때, 크기를 동일하게 유지한 상태에서 깊이차원을 확장하면 나)와 같 이 되는데, 크기와 깊이 두 차원을 모두 고려하면 나)는 가) 와 3차원 모양이 다르다. 곡률개념으로 표현하면 나)의 곡 률이 가)의 곡률보다 크다. 반면, 다)는 가)보다 깊이가 크지 만 크기도 같은 비율로 증가하였기 때문에 가)와 다)의 3차 원 모양 즉 곡률은 동일하다. 나)와 다)의 깊이는 동일하지 만 크기가 상이하기에 나)와 다)의 모양 즉 곡률은 상이하 고 특히 나)의 경우 크기에 비하여 깊이가 크기 때문에 크 기와 깊이가 동일한 다) 보다 곡률이 크다. 이처럼, 곡률은 2 개의 차원 즉 크기차원과 깊이차원을 동시에 고려한 개념 으로써 깊이와 관계는 있지만 개념상 독립적인 개념이며, $3 \mathrm{D}$ 디스플레이에 제시되는 3 차원 자극 속성의 지각왜곡에 있어서 독립적으로 고려되어야 할 속성들이다.

\section{$1.43 \mathrm{D}$ 디스플레이에서의 깊이/모양 지각의 왜곡}

자연 $3 \mathrm{D}$ 환경에 존재하는 3 차원 대상의 깊이와 모양이 관찰거리에 관계없이 항상성 있게 지각되는 것과 달리, 인 공의 $3 \mathrm{D}$ 디스플레이에 제시되는 대상은 디스플레이까지의 관찰거리에 따라서 깊이와 모양이 왜곡되어 지각되는데, 그 이유는 다음과 같다. 자연 $3 \mathrm{D}$ 환경에서 특정대상의 깊이 에 대응하는 양안시차 양은 관찰거리의 제곱에 반비례 한 다. 반면에, 특정 대상에 대한 3D 영상(좌안 영상과 우안 영상)은 카메라와 대상까지의 거리에 따라서 좌안영상과 우안영상의 시차, 즉 양안시차가 촬영거리 제곱에 반비례 
하여 변화하겠지만, 일단 촬영된 3D 영상이 3D 디스플레이 에 제시될 때 발생하는 화면시차(screen disparity)는 고정 적이다. 이 화면시차는 시청자가 $3 \mathrm{D}$ 디스플레이에 가깝게 다가서던 또는 3D 디스플레이로부터 멀어지던 변화하지 않는다. 화면에 제시되는 좌우영상의 차이 즉 화면시차는 시청거리에 의해 변화하지 않고 촬영시의 대상과 카메라 사이의 거리인 촬영거리에 의해서만 변화한다. 이와 같은 자연 $3 \mathrm{D}$ 환경과 인공 $3 \mathrm{D}$ 디스플레이상에서의 관찰거리에 따른 양안시차(또는 화면시차)의 변화패턴에서의 차이 때 문에 자연 환경에서는 관찰되지 않는 깊이/모양 지각 왜곡 이 $3 \mathrm{D}$ 디스플레이에서 관찰된다.

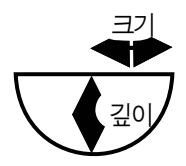

가)

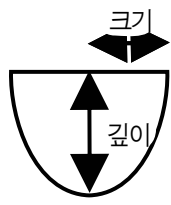

나)

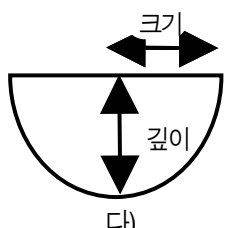

다)
그림 2. $3 \mathrm{D}$ 깊이와 $3 \mathrm{D}$ 모양 (자세한 내용은 본문 참조)

Fig 2. 3D depth and 3D shape (refer to the text for detail)

\section{2. $3 \mathrm{D}$ 깊이모양 지각감 왜곡 측정 도구 개발}

$3 \mathrm{D}$ 깊이감/모양감 지각 왜곡을 측정하는 도구는 크게 자 극 구성, 자극 제시 그리고 지각왜곡 측정부 세 개의 부분으 로 구성되어 있다.

\section{1 자극 구성}

$3 \mathrm{D}$ 깊이/모양이 왜곡되게 지각된 정도를 측정하기 위해 서는 실제 특정 깊이와 모양을 갖는 사물을 모사(simulation)할 필요가 있다. 본 연구에서는 시청자에게 친숙한 사 물이면서 동시에 깊이감과 모양감을 쉽게 보고할 수 있는 사물인 반 원통체(또는 반 타원기둥체)를 모사하였다. 본 연구에서는 자극 구성과 깊이 및 모양지각감 측정에서의 효율성을 높이기 위해서 반 원통체를 모사하고 실험에 이 용하였다. 연구문제에 따라서 본 연구에서 제안하는 측정 방법을 대상의 모양과 깊이를 변화시킨 자극에 적용하는 것이 가능하다. 본 연구에서 측정하고자 하는 표면 곡률(크
기 차원의 변화에 따른 깊이 차원에서의 변화)에서의 지각 감 측정에는 원통체 자극이 적절한데, 왜냐하면 곡률의 개 념을 최대 크기 대비 최대 깊이의 비율로 규정하는 것이 가능하고 이것이 직관적 개념과도 일치하기 때문이다. 이 와 같은 이유에서 3 차원 깊이와 모양지각 연구에서 원통체 를 자극으로 사용하는 것은 일반화되어 있다 ${ }^{[5,6]}$.

반원통체에 대한 3차원 정보인 양안시차(binocular parallax)를 2D 화면에 재현하기 위해서는 3차원 사물의 수리적 모형, 수리적 모형과 시청자 사이의 관찰거리, 시청자 개인 의 양안간 거리가 규정되어야 한다. 본 연구에서 구성한 원 통체의 $\mathrm{x}$ 축에서의 각 점의 깊이에 대한 수리적 모형은 다음 식 (1)과 같다.

$$
d_{x}=(s / 4) \sqrt{r^{2}-d_{o x}^{2}}
$$

식 (1)에서 $d_{x}$ 는 $x$ 에서의 깊이를 나타내고, $s$ 는 모양계 수를 나타내며, $r$ 은 원통체의 반지름을 나타내고, $d_{o x}$ 는 원 통체 중심에서 $x$ 까지의 거리를 나타낸다. 식 (1)에서 원통 체의 반지름과 모양계수는 표 1 에 제시되어 있다. 표 1 에서 $s 1, s 2$ 등은 모양계수 $s$ 를 나타낸다. 식 (1)을 이용하여 실험 자극을 구성하였는데, 실험에 사용된 반원통체는 $y$ 축상에 서의 깊이는 모두 동일하고 단지 $x$ 축 상에서의 깊이만 상 이하다. 식 (1)은 $y$ 축의 값과 관계없이 반원통체를 구성하 는 $x$ 축에서의 각 점들의 깊이를 나타내는 것으로서 기본적 으로 원의 공식과 유사하다. 다만 실험에 사용되는 타원기 둥체의 곡률을 고려하여 $(s / 4)$ 가 계수로 이용되었고, $s$ 가 $s 4$ 인 경우에는 $x$ 축에서의 깊이의 집합은 완벽한 원형을 이 루게 된다.

표 1. 3D 깊이감모양감 지각 왜곡 측정에 사용된 반타원기둥체의 척도(단위 $\mathrm{cm}$ ) Table 1. Scales of the half-cylinders employed in the measurement of the perceptual distortion of 3D depth/shape $(\mathrm{cm})$

\begin{tabular}{|c|c|c|c|c|c|c|c|}
\hline$r$ & $s 1$ & $s 2$ & $s 3$ & $s 4$ & $s 5$ & $s 6$ & $s 7$ \\
\hline 3.51 & 0.88 & 1.76 & 2.63 & 3.51 & 4.39 & 5.27 & 6.14 \\
\hline 3.9 & 0.98 & 1.95 & 2.93 & 3.9 & 4.88 & 5.85 & 6.83 \\
\hline 4.29 & 1.07 & 2.15 & 3.22 & 4.29 & 5.36 & 6.44 & 7.51 \\
\hline
\end{tabular}

본 연구에서는 매트랩(Matlab) 환경에서 실시간 렌더링 
툴인 OpenGL을 이용하여 표 1의 깊이와 크기를 갖는 반타 원기둥체 21 개를 3 개의 관찰거리 $90 \mathrm{~cm}, 110 \mathrm{~cm}, 130 \mathrm{~cm}$ 에 걸쳐서 모사하였다. 표에서 크기는 반타원형기둥체의 반지 름(그림 2 참조)을 나타내고, 동일 모양(곡률)을 갖도록 깊 이(그림 2 참조)를 모양의 크기에 맞게 체계적으로 구성하 였다. 표 1 에서 각 $\mathrm{s}$ 열에 있는 수치는 반타원형기둥체의 깊 이를 나타낸다. 예를 들어, $\mathrm{s} 4$ 는 완벽한 반원통체로서 세 가 지 크기를 갖는 반원통체의 척도를 나타낸다. $\mathrm{s} 4$ 의 가장 작 은 크기는 $3.51 \mathrm{~cm}$ 인데, 이때 $\mathrm{s} 4$ 의 깊이가 $3.51 \mathrm{~cm}$ 로서 반지 름과 깊이가 동일하기 때문에 완벽한 반 원통체가 된다. 그 림 3은 무선점 애너글리프 형태로 제시되었던 $\mathrm{s} 4$ (반원통체) 를 나안으로 관찰할 수 있도록 재구성한 무선점 입체그림 (RDS: Random Dot Stereogram) 자극 예이다. 그림 3의 좌 측은 좌안영상, 우측은 우안영상이다. 실험상황에서 피험자 가 경험한 지각감을 경험하기 위해서는 자극의 크기, 관찰 거리, 양안간 거리 조건이 모두 충족되어야하는데, 그림 3은 단지 실험에서 제시된 자극에 대한 도식적인 예일 뿐이다.

일반 3D 디스플레이 환경에서 3D 깊이/모양 지각 왜곡 이 발생하는 원인은 자연 3D 환경과 상이하게 양안시차가 관찰거리 변인에 따라 달리 작동하기 때문이다. 양안시차 이외의 $3 \mathrm{D}$ 관련 변인의 효과를 제거하기 위해서 평행투사 법(parallel projection)을 사용하여 표 1에 제시된 척도를 갖 는 사물을 모사하였고, 같은 이유로 가능한 한 $3 \mathrm{D}$ 지각에 대한 단안정보(monocular 3D inoformation)를 배제하기 위 하여 무선점 입체그림쌍(RDS, random dot stereogram)을 구현하였다.
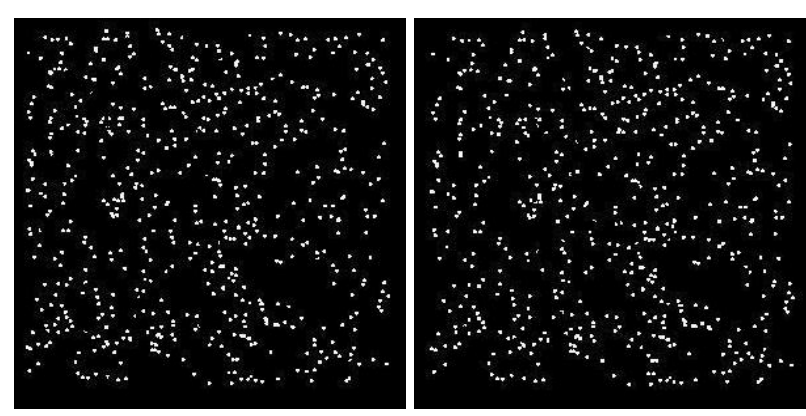

그림 3. 모양계수 $s 4$ 로 구성된 애너클리프 자극의 RDS 버전 자극 예 Fig 3. An example stimulus of a random dot stereogram version of the anaglyph type stimulus simulating with the shape parameter s4
표 1 에 제시된 척도를 갖는 사물을 무선점 입체 그림 쌍 으로 모사하는데 필요한 양안간 거리 파라미터는 실제 측 정대상이 되는 시청자의 양안간 거리를 측정하여 입력하도 록 모사 프로그램을 구성하였다. 본 연구에서 모사된 자극 은 실험공간의 특성상 17 인치 모니터에 제시되도록 상대적 으로 작은 크기의 대상이 모사되었다. 대형화면에서의 측 정을 염두에 둔다면 표 1 에 제시된 척도를 동일한 배율로 확대하여 사용하는 것이 가능하다.

\section{2 자극 제시}

모사된 자극은 17 인치 LCD 모니터에 애너글리프 (anaglyph) 형식으로 제시되었는데 좌안영상은 적색, 우안 영상은 녹색의 점으로 겹쳐서 제시되도록 하였으며 시청자 는 적녹 안경을 착용하고 제시된 자극을 관찰하였다. 본 연 구에서는 제한된 연구 환경 때문에 애너글리프 형식으로 자극을 구성하고 제시하였지만, 자극제시방법은 편광방식, 무안경식 등 다양한 형태로 구현하는 것이 가능하다.

\section{$2.33 \mathrm{D}$ 깊이감/모양감 왜곡 측정}

시청자는 앞서 기술한 3 가지 크기 7 가지 모양을 갖도록 $50 \mathrm{~cm}$ 관찰거리를 전제로 모사한 총 21개 반타원기둥체를 $50 \mathrm{~cm}, 110 \mathrm{~cm}$, 그리고 $130 \mathrm{~cm}$ 관찰거리에서 관찰하면서 제 시된 사물의 $3 \mathrm{D}$ 지각 왜곡 정도를 측정 받았다. 깊이감과 모양감 왜곡은 독립된 세션에서 측정되었는데, 각 세션에 서 시청자들은 세 개의 관찰거리에서 측정되었다. 측정의 변산성을 최소화하기 위하여 각 자극은 각 관찰거리에서 10 회 반복 측정되도록 하였다. 따라서 각 관찰거리에서 시 청자는 총 210회(21개 자극 X 10회 반복=총 210회)에 걸쳐 측정 받았다. 본 연구에서는 총 10 명의 시청자가 실험에 참 여하였다. 모든 시청자는 21 개의 자극을 세 관찰거리에서 모두 측정 받았다. 연습효과를 상쇄시키기 위하여 5명의 피 험자는 가까운 관찰거리부터 측정 받고 후에 먼 관찰거리 에서 측정 받았으며 나머지 5명은 먼저 먼 관찰거리에서 측정 받았고 후에 가까운 관찰거리에서 측정 받았다.

깊이감 왜곡 측정 세션에서 관찰자의 주어진 대상에 대 한 깊이감은 강도추정법을 이용하여 측정되었다. 관찰자에 게 주어진 대상의 깊이감 판단의 기준을 제공하기 위하여 
$\mathrm{s} 4$ (깊이와 크기가 동일한 반원통체)에 대하여 지각된 깊이 감을 “20”이라고 보고하도록 하였다. 예를 들어 지각된 깊 이감이 s4의 깊이감보다 2배로 크게 지각되면 “40”이라고 보고하도록 하였고, 반대로 $s 4$ 의 깊이감보다 $1 / 2$ 로 작게 지 각되면 “ 10 ”이라고 보고하도록 하였다. 모양감 왜곡 측정 세션에서도 s4의 모양감(곡률)을 “20”으로 제시하고 깊이 감 에서의 보고 방법과 동일한 방법으로 모양감을 보고하 도록 하였다. 예를 들어, s4의 경우 크기와 깊이가 동일한 데, 크기에 비해 깊이가 2 배로 지각되면 “40”이라고 모양감 을 보고하도록 하였고, 크기에 비해 깊이가 $1 / 2$ 로 작게 지 각되면 “ 10 ”이라고 모양감을 보고하도록 하였다. 깊이감과 모양감(곡률) 모두 깊이 차원을 고려한다는 면에서 동일하 지만 모양감은 크기차원 대비 깊이차원에서의 지각감 비율 을 의미한다. 모양감 지각 과제 수행에 크기지각 메카니즘
과 깊이지각 메카니즘이 복합적으로 관여할 수 있기에 깊 이감과 독립적으로 모양감을 측정하는 것이 의미가 있다.

\section{3. $3 \mathrm{D}$ 깊이모양 지각 왜곡의 측정 결과}

\section{1 깊이감 왜곡 측정 결과}

피험자의 안정적인 깊이감 지각을 추정하기 위하여 21개 조건 각 각에 대하여 10 회 반복 측정한 값의 평균을 계산하 였다. 세 가지 관찰거리에서 21개 대상의 깊이감에 대한 10 명 피험자의 반응은 대체적으로 유사하였다. 따라서, 10 명 피험자의 반응을 각 조건별로 평균하여 깊이감 왜곡 정도 를 계산하였다. 그림 4는 7가지 자극 깊이(자극 종류)및 세 가지 크기에 대한 21개 대상의 세 가지 관찰거리별 지각된 깊이감을 나타낸다.
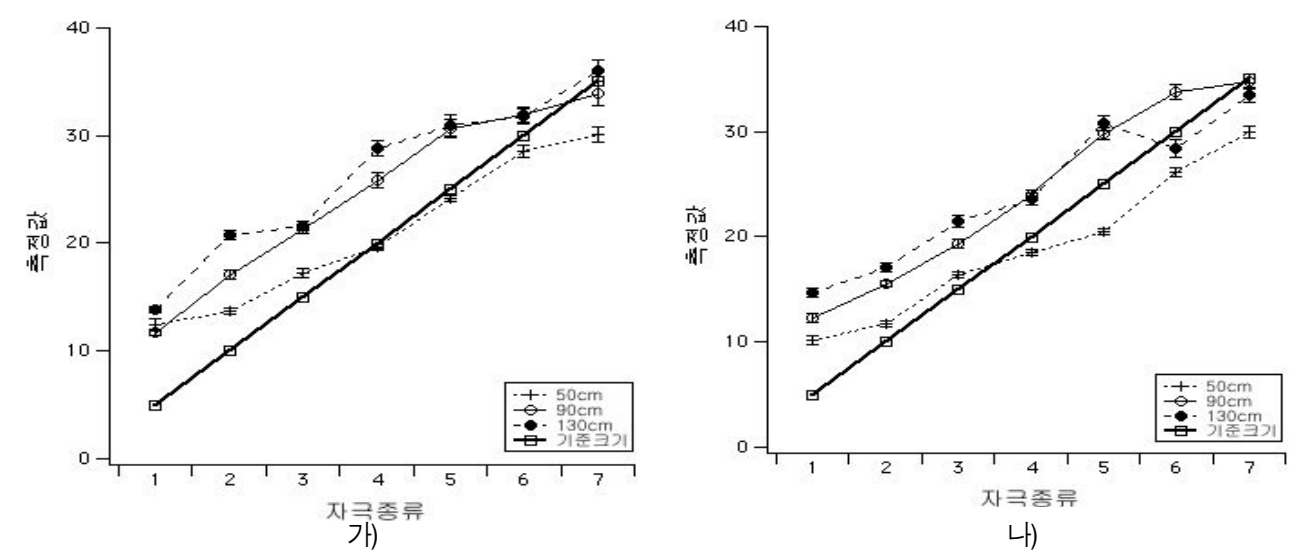

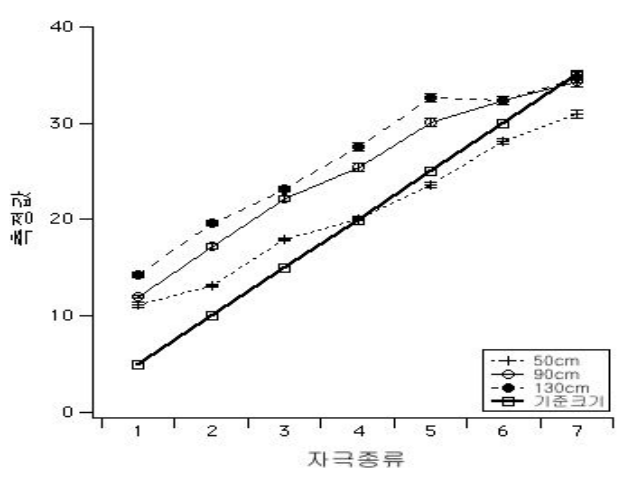

다)

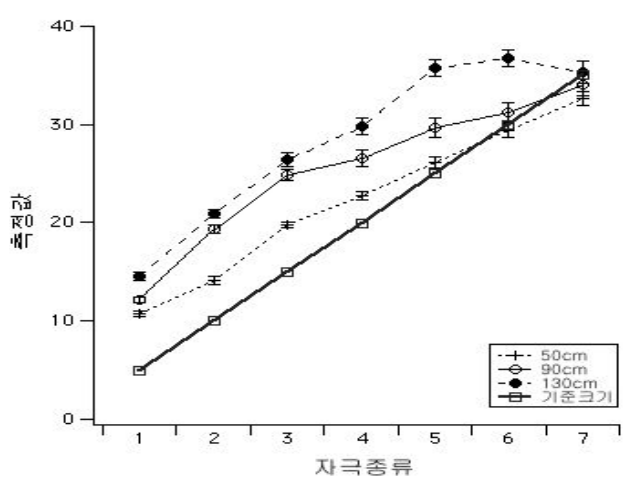

라)

그림 4. 대상의 7 가지 모양계수(s, 자극종류) 및 세 가지 관찰거리에 따른 지각된 깊이감 측정치

Fig 4. The measurements of the perceived depth along with 7 shape parameters and 3 viewing distances 
그림 4의 가)는 세 가지 크기의 자극에 대한 깊이감 지각 데이터를 통합한 자료이며 그림 4의 나), 다), 라)는 각각 크기 $3.51,3.9,4.25 \mathrm{~cm}$ 에 대한 대상의 깊이 지각감을 나타 낸다. 그림에서 굵은 실선은 기준자극(모양 4 인 반 원통체) 의 값으로 제시한 " 20 "과 실제 자극의 깊이를 고려하였을 때 피험자가 대상의 깊이를 올바르게 지각하였다는 것을 전제로 보고할 수 있는 예상 깊이감(즉 제시된 자극의 수학 적인 모형을 고려할 때 이상적으로 지각되어야 하는 깊이 감)을 나타낸다. 지각된 깊이감이 실선과 가까울수록 모양 지각 왜곡이 작고 멀어질수록 모양지각 왜곡이 많았음을 나타낸다. 관찰거리 $50 \mathrm{~cm}$ 에서 지각한 깊이감이 다른 관찰 거리에서의 깊이감보다 굵은 실선과 가깝고 관찰거리가 $90 \mathrm{~cm}$ (가는 실선), 그리고 $130 \mathrm{~cm}$ (파선)로 멀어질수록 동일
자극에 대하여 지각하는 깊이감도 상대적으로 커지는 것을 알 수 있다. 예를 들어 그림 4의 가)에서 자극종류 4(s4)가 완벽한 반원통체인데, 이 자극에 대하여 피험자들은 관찰 거리 50 일 때 “20”이라고 깊이감을 보고한데 반하여, 관찰 거리 $90 \mathrm{~cm}$ 에서는 약 “ 25 ” 그리고 관찰거리 130 에서는 약 “28”이라고 깊이감을 보고하였다. 이와 같은 경향성은 모 든 자극종류에서 일관되게 관찰되었다. 동일한 경향성이 자극의 깊이가 상이할지라도 일관되게 관찰됨을 그림 4의 나), 다) 및 라)에서 확인할 수 있다.

\section{$3.23 \mathrm{D}$ 모양감 왜곡 측정 결과}

그림 5는 본 실험에서 사용한 동일한 자극에 대한 세 가 지 관찰거리에서의 10 명 피험자의 $3 \mathrm{D}$ 모양감(곡률감) 평

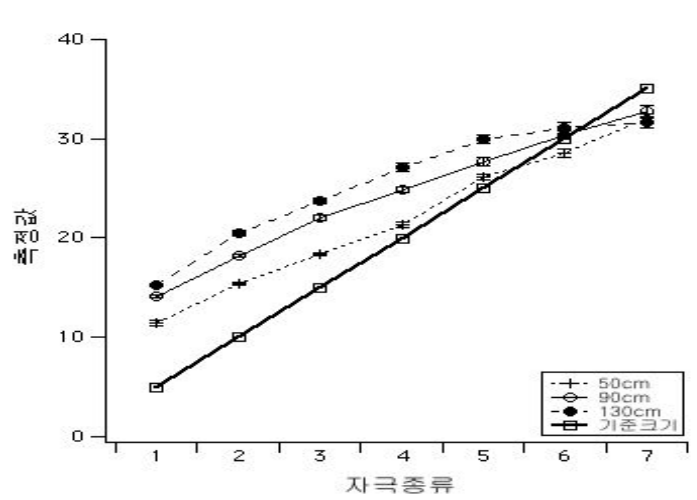

가)

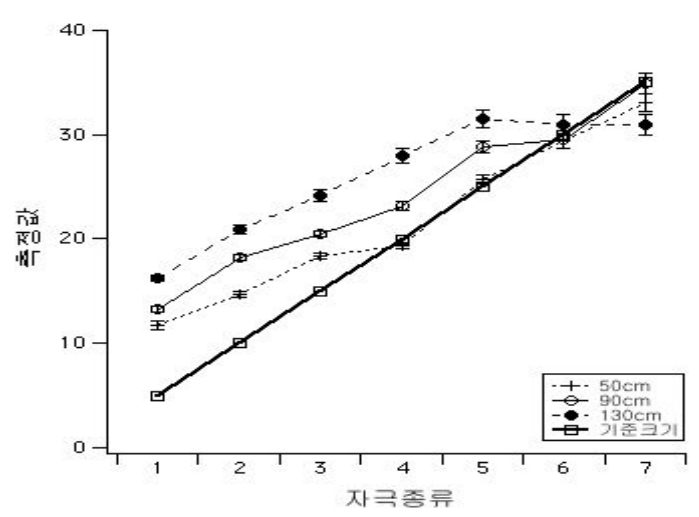

다)

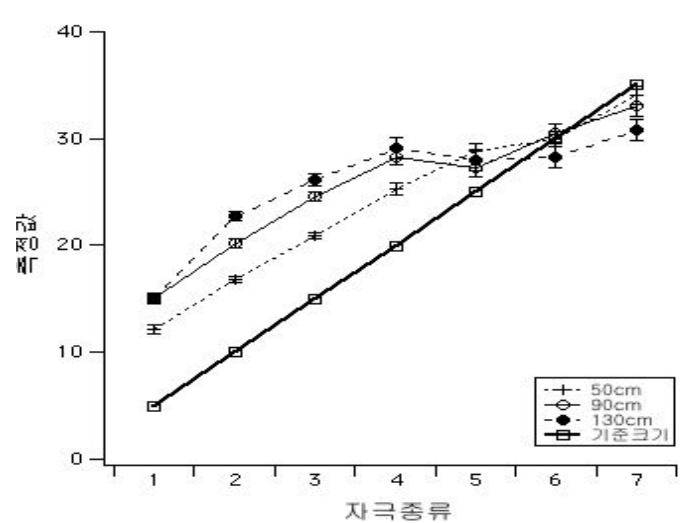

나)

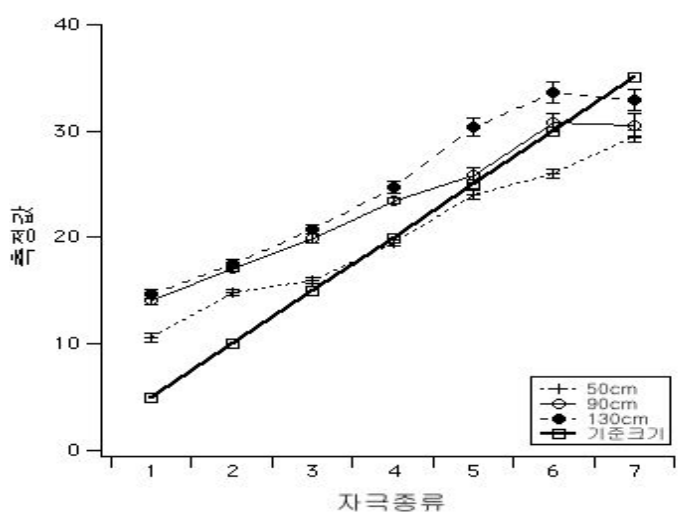

라)

그림 5. 대상의 7 가지 모양계수(s, 자극종류) 및 세 가지 관찰거리에 따른 지각된 모양감(곡률) 측정치.

Fig 5. The measurements of the perceived shape along with 7 shape parameters and 3 viewing distances 
균치를 나타낸다. 그림 5 의 가)는 세 가지 깊이를 통합한 자료의 평균 모양감을 나타내고 나), 다)및 라)는 각 각 크 기 $3.51,3.9,4.25 \mathrm{~cm}$ 인 대상을 세 가지 관찰 거리에서 관찰 했을 때의 지각된 모양감 평균치를 나타낸다.

그림 4와 마찬가지로 굵은 실선은 대상의 모양(곡률)을 제대로 지각하였을 때 예상되는 측정치를 나타낸다. 그림 5 의 가)에 나타나 있듯이 대상과 관찰자까지의 거리가 $50 \mathrm{~cm}$ 임을 전제로 모사한 대상을 실제 관찰거리 $50 \mathrm{~cm}$ 에서 관찰할 때 지각된 모양감이 굵은 실선(실제 모양감을 제대 로 지각했을 때 예상되는 측정치)과 가장 가까웠다. 예를 들어, s4는 완벽한 반원통체인데, 피험자들은 $\mathrm{s} 4$ 의 지각된 모양감을 “20"에 가깝게 보고하였다. 하지만, 관찰거리가 $90 \mathrm{~cm}$ 일 때는 동일한 대상을 “25”라고 보고하였고 관찰거 리가 $130 \mathrm{~cm}$ 일 때는 “ 28 ”이라고 보고하였다. 동일한 반응 패턴이 다른 모양에서도 반복되어서 관찰되었고, 이러한 반응양상은 다른 크기를 갖는 대상 전체에서 일관되게 관 찰되었다(그림 5의 나), 다) 및 라) 참조).

\section{III. 논의 및 결론}

$3 \mathrm{D}$ 모양을 관찰거리에 관계없이 실감있게 감상할 수 있 게 하기 위해서는 먼저 현재의 실감방송 및 $3 \mathrm{D}$ 디스플레이 가 어느 정도의 깊이감/모양감 왜곡을 유발하는지 수량화 하여 객관적으로 측정할 수 있는 깊이감/모양감 왜곡 측정 도구가 필요하다. 본 연구는 다양한 형태의 원통형 또는 타 원형의 3 차원 기둥체가 특정 관찰거리에서 관찰될 때 획득 되는 양안시 자극을 모사하고, 이를 특정 관찰거리에서 관 찰할 때 지각되는 깊이감/모양감을 측정하면서 동시에 관 찰자가 보고한 깊이감/모양감이 실제의 깊이/모양과 얼마 나 일치하는지 또는 얼마나 과장/축소되어 보고되는지의 왜곡정도를 판가름할 수 있는 깊이감/모양감 왜곡 측정도 구를 구현하였다.

실제 10 명의 피험자를 대상으로 $50 \mathrm{~cm}$ 관찰거리를 전제 로 모사한 대상을 $3 \mathrm{D}$ 디시플레이에 제시하고 $50 \mathrm{~cm}, 90 \mathrm{~cm}$, $130 \mathrm{~cm}$ 관찰거리에서 대상의 깊이감과 모양감을 측정한 결 과, 관찰거리 $50 \mathrm{~cm}$ 에서 실제 모사한 대상과 가장 근접하게
깊이감과 모양감을 지각하였다. 하지만 관찰거리가 $90 \mathrm{~cm}$, $130 \mathrm{~cm}$ 로 증가함에 따라서 지각되는 깊이감과 모양감(특히 곡률감)이 $25 \% \sim 40 \%$ 가량 증가하는 것으로 관찰되었다. 이러한 실험결과는 관찰거리가 증가함에 따라서 지각되는 모양감이 체계적으로 왜곡됨을 시사하며 주목해야할 것은 그 왜곡되는 정도를 본 연구에서 개발한 깊이감/모양감 왜 곡 측정도구가 측정한다는 것이다. 동일 입체 영상에 대하 여 관찰거리가 증가할수록 깊이감과 곡률이 증가하는 것으 로 지각되는 이유는 아마도 우리의 시각체계가 동일 영상을 증가된 관찰거리로 재척도화 했기 때문인 것으로 판단된다.

Cardboard effect 또는 Puppet Theater Effect와 같이 크 기감과 깊이감이 실제보다 왜곡된다는 보고는 있어왔지만 $[10,11,12,13,14]$, 깊이감과 모양감이 왜곡되는 정도를 양화하여 측정할 수 있는 도구는 현재까지 보고된 바가 없다. 스테레 오스코픽 비디오 시스템에서 이미지지가 카메라간 거리, 수렴거리, 시야각, 스크린 크기, 촬영 방위등에 따라서 어떻 게 변화하고 왜곡되는지에 대한 분석은 있었다 ${ }^{[1,2]}$. 하지만, 이와 같은 이미지 왜곡은 기하학적 법칙에 의해서 결정되 는 것이며 이미지 상에서의 왜곡이 지각적 왜곡에 어떤 영 향을 미치는지를 규명하기 위해서는 지각감 왜곡 측정 도 구를 이용한 추가적인 연구가 필요하다. 본 연구에서 제안 하는 깊이감/모양감 왜곡 측정 기법은 스테레오스코픽 비 디오 시스템에서의 관련 파라미터 변화에 따른 이미지 변 화 및 왜곡이 지각적 왜곡에 어떤 영향을 주는지 규명하는 데에 이용될 수 있다.

기술의 발전을 위해서 현재 기술의 문제점을 정확히 수 량화하여 진단하는 것이 중요한데, 이러한 진단에 가장 기 본이 되는 것이 문제가 되는 변인의 측정이다. 어떻게 하면 실제 대상의 깊이감과 모양감을 그대로 전달할 수 있는 3D 디스플레이를 개발할 것인가의 문제가 남아있지만 본 연구 에서 구성한 $3 \mathrm{D}$ 깊이/모양 지각감 왜곡 측정 도구는 현재의 기술이 안고 있는 깊이감/모양감 왜곡의 문제를 진단하고 그 정도를 파악할 수 있는 새로운 기술 개발을 위한 중요한 출발점이 될 것이다. 


\section{참 고 문 헌}

[1] Woods, A., Dochetry, T. \& Koch, R., Image distortions in stereoscopic video systems, Proceedings of SPIE Vol.1915, pp.36 48, 1993

[2] 김성규, 스테레오 방식의 $3 \mathrm{D} \mathrm{TV}$ 를 위한 3차원 영상의 촬영과 표시 그 리고 관찰자와 관련된 왜곡, 방송공학회지, Vol.13 No.1, pp.38 44, 2008

[3] Todd, J. T. \& Norman, J. F., Distortions of perceived 3-D structure in natural vision, Annual meeting of the Psychonomic Society, November, 1995

[4] Jain,, R. A., Tsina, L. \& Durgin, F. H., Stereoscopic 3-D shape constancy with real objects in the real world: effects of contextual disparity contrast, Investigative Ophthalmology and Visual Science, Vol.38, S904, 1997

[5] Sedgwick, H. A., Space perception, Handbook of Perception and Performance(Ch. 21, pp.1 57), Willy, New York, 1986

[6] Johnston, E. B., Systematic distortions of shape from stereopsis, Vision Research, Vol.31, pp.1351 1360, 1991

[7] Rogers, B. J. \& Cagenello, R. B., Disparity curvature and the perception of three-dimensional surfaces, Nature, Vol.339, pp.135 137, 1989
[8] Todd, J. T. \& Norman, J. F., Distortions of perceived 3-D structure in natural vision, Annual meeting of the Psychonomic Society, November, 1995

[9] Jain,, R. A., Tsina, L. \& Durgin, F. H., Stereoscopic 3-D shape constancy with real objects in the real world: effects of contextual disparity contrast, Investigative Ophthalmology and Visual Science, Vol.38, S904, 1997

[10] Landy, M. S. \& Movshon, J. A., Computational models of visual processing-shape from X, Psychophysics and Computation, MIT Press, Cambridge, pp.306 330, 1991

[11] MacAdam, D. L., Stereoscopic perceptions of size, shape, distance and direction, SMPTE J., Vol.62, pp.271 289, 1954

[12] Yamanoue, H., Okui, M. \& Yuyama, I., A study on relationship between shooting conditions and cardboard effect of stereoscopic images, IEEEE Trans. Curcuits Syst. Video Technol., 10, April, 2000

[13] Komatsu, T. \& Pastoor, S., Puppet theater effect observing stereoscopic images, Tech. Rep. of IEICE, IE92 104, pp.39 46, 1993

[14] Yamanoue, H., Okui, M. \& Okano, F., Geometrical analysis of puppet-theater and cardboard effects in stereoscopic HDTV images, IEEEE Trans. Curcuits Syst. Video Technol., Vol.16, pp.744 752, June, 2006

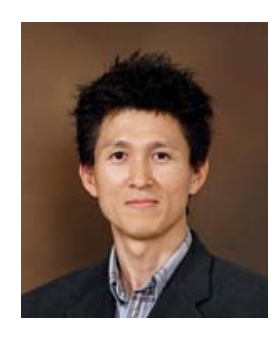

\section{이 형 철}

- 1987년 : 연세대학교 심리학과 학사

- 1989년 : 연세대학교 대학원 심리학과 석사

- 1996년 : Univ. of Wisconsin - Madison 심리학과 Ph.D.

- 1997년 1999년 : McGill Vision Research Center 연구원

- 1999년 현재 광운대학교 산업심리학과 정교수

- 2009년 현재 인지과학 편집위원장

- 주관심분야 : 3D 휴먼팩터, 시각과학, Brain-Computer Interface 